\title{
Farm data analysis for lifetime performance components of sows and their predictors in breeding herds
}

\author{
Yuzo Koketsu* and Ryosuke lida
}

\begin{abstract}
Our objectives in this review are 1) to define the four components of sow lifetime performance, 2) to organize the four components and other key measures in a lifetime performance tree, and 3) to compile information about sow and herd-level predictors for sow lifetime performance that can help producers or veterinarians improve their decision making. First, we defined the four components of sow lifetime performance: lifetime efficiency, sow longevity, fertility and prolificacy. We propose that lifetime efficiency should be measured as annualized piglets weaned or annualized piglets born alive which is an integrated measure for sow lifetime performance, whereas longevity should be measured as sow life days and herd-life days which are the number of days from birth to removal and the number of days from date of first-mating to removal, respectively. We also propose that fertility should be measured as lifetime non-productive days, whereas prolificacy should be measured as lifetime pigs born alive. Second, we propose two lifetime performance trees for annualized piglets weaned and annualized piglets born alive, respectively, and show inter-relationships between the four components of the lifetime performance in these trees. Third, we describe sow and herd-level predictors for high lifetime performance of sows. An example of a sow-level predictor is that gilts with lower age at first-mating are associated with higher lifetime performance in all four components. Other examples are that no re-service in parity 0 and shorter weaning-to-first-mating interval in parity 1 are associated with higher fertility, whereas more piglets born in parity 1 is associated with higher prolificacy. It appears that fertility and prolificacy are independent each other. Furthermore, sows with high prolificacy and high fertility are more likely to have high longevity and high efficiency. Also, an increased number of stillborn piglets indicates that sows have farrowing difficulty or a herd health problem. Regarding herd-level predictors, large herd size is associated with higher efficiency. Also, herd-level predictors can interact with sow level predictors for sow lifetime performance. For example, sow longevity decreases more in large herds than small-tomid herds, whereas gilt age at first-mating increases. So, it appears that herd size alters the impact of delayed gilt age at first-mating on sow longevity. Increased knowledge of these four components of sow lifetime performance and their predictors should help producers and veterinarians maximize a sow's potential and optimize her lifetime productivity in breeding herds.
\end{abstract}

Keywords: Farm data, Fertility, Lifetime efficiency, Lifetime performance, Longevity, Prolificacy

\footnotetext{
* Correspondence: koket001@isc.meiji.ac.jp

School of Agriculture, Meiji University, Higashi-mita 1-1-1, Tama-ku, Kawasaki, Kanagawa 214-8571, Japan
} 


\section{Background}

Farm data are collected and stored on a daily basis by recording software in breeding herds. However, most producers only use the data to generate basic reports such as sow cards, working lists and a brief performance summary, and so do not use their farm data to its full potential [1]. Herd management based on farm data analysis [1] can help producers and veterinarians to maximize lifetime reproductive potential of sows to improve economic inefficiency [2-4]. Also, farm data analysis can accurately monitor lifetime performance in individual sows including the four components of longevity, prolificacy, fertility and lifetime efficiency measures, which were well used, but were not well organized to understand.

As a simple benchmark, the number of piglets weaned per sow per year (PSY) has been commonly used for monitoring changes in performance within a herd or for comparing PSY between herds [4, 5]. However, even though PSY is a good measurement for herd productivity in the short term, it is not the best measurement for sow lifetime performance including longevity [2, 4, 5]. Also, sow lifetime performance and inter-relationships between the four components have not been well studied, even though PSY and inter-relationships between key components are well known as a productivity tree $[4,5]$.

Also, sow lifetime performance can be predicted to a certain degree using reproductive performance factors [5] which are sow level predictors and herd-level predictors. Sow and herd-level predictors include age at firstmating, re-service in parities 0 and 1 , the number of pigs born alive at parity 1 , the number of stillborn piglets at parity 1 , weaning-to-first-mating interval in parity 1 , culling guidelines, timing of insemination and highperforming herds $[4,5]$. Using such predictors, producers and veterinarians could maximize a sow's potential and optimize her lifetime productivity. Therefore, this review aims to characterize the four components of sow lifetime performance, to propose inter-relationships between the four components and other key measures, and to summarize predictors for high lifetime performance of sows. Also, statistical methods for farm data analysis at herd-level or sow level have been developed over the last four decades using observational study concepts in epidemiology [5]. However, farm data analysis, especially for individual sow data, is still not well recognized as a valid scientific approach. Therefore, in this review we will emphasize the potential benefits of these methods.

\section{Review}

\section{Limitation of piglets weaned per sow per year (PSY) as} benchmark

PSY has been used widely as an integrated herd productivity measurement in North America for three decades $[4,6]$. In the calculation, PSY is simply defined as the number of pigs weaned per litter multiplied by the number of litters farrowed per sow per year. However, it does not include any measure of longevity. In fact, more PSY is not directly associated with higher longevity, measured as the mean parity of removed sows or mean sow life days [7]. Also, some producers tend to cull low parity sows with fewer PBA to increase their herd's PSY [8]. However, this means that the sows culled at low parity will not be able to realize their latent reproductive potential during herd-life. Also, high sow longevity can increase the profit per sow because lifetime PW by parity 3 is sufficient to recover the initial cost of a replacement gilt [2].

\section{Components of sow lifetime performance in breeding herds}

Sow lifetime performance can be categorized as the four components of longevity, prolificacy, fertility and lifetime efficiency of sows. Longevity is measured as the number of parity at removal [2-4], herd-life days $[9,10]$ or sow life days. Sow life days is the number of days from birth to removal, whereas herd-life days is the number of days from the date that a sow is first-mated as a gilt to the removal date. In order to compare herd-life days between herds, it should begin from the day that gilts are first-mated, because the age of gilt entry to a herd can vary from the first day of a gilt piglet is weaned to the day that the replacement gilt is first-mated. Also, removal can be due to culling, death, euthanasia or being transferred.

A sow's prolificacy should be measured as lifetime piglets born alive from first farrowing to removal. Fertility can be represented as herd-life nonproductive days, which contains the weaning-to-first-mating interval during herd-life, plus the re-service interval from the date that a sow is first-mated as a gilt until its removal $[4,5]$.

Sow life or herd-life annualized piglets born alive (PBA) is a measurement of sows' lifetime efficiency that includes prolificacy, fertility and longevity [5]. Another measurement of sows' efficiency is sow life or herd-life annualized piglets weaned (PW), which combines annualized PBA with lactational performance [5]. Annualized PBA simply combines prolificacy, fertility and longevity, whereas annualized PW contains additional lactational performance factors such as pre-weaning mortality, sow milk yields, nursing behavior and management practices (e.g. nursing and fostering techniques), that will reflect management and facility impacts.

Figure 1 shows the inter-relationships between the four components and other key measures for sow life annualized PW using theoretical value examples. Sow life annualized PW is the product of two components: sow life days and lifetime PW. Sow life days is the number of days from birth to removal, which is also derived 


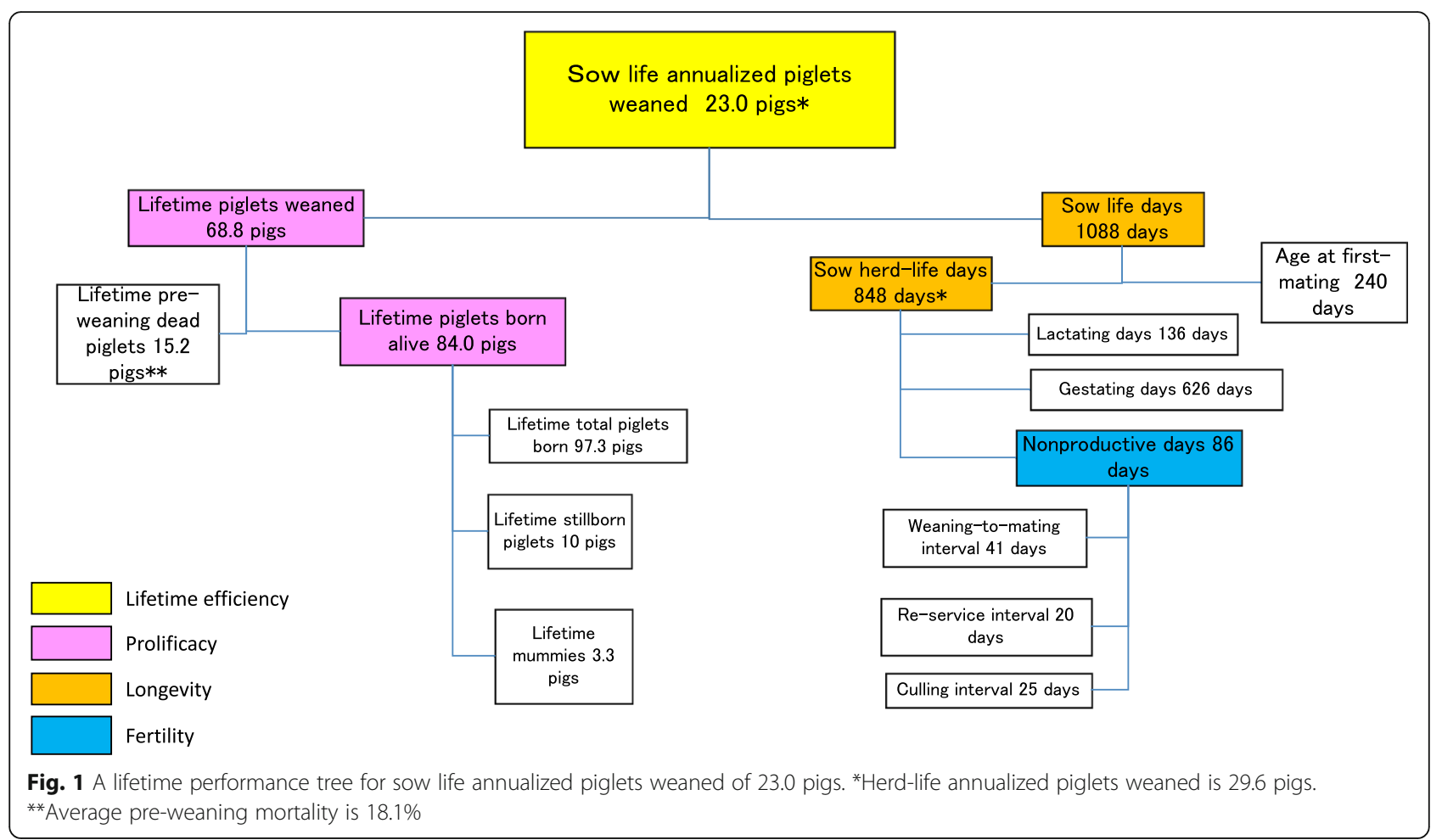

from age at first-mating (AFM) plus herd-life days. Herd-life days includes lactating days, gestating days and nonproductive days. Herd-life annualized PW is also obtained from herd-life days and lifetime PW. In addition, the number of farrowings or the number of parity at removal can be roughly estimated by dividing gestating days during herd-life by 115 days (e.g. 626 gestating days divided by 115 is 5.4). Additionally, Fig. 2 shows the inter-relationships between the four components and other key measures for sow life annualized PBA. Sow life

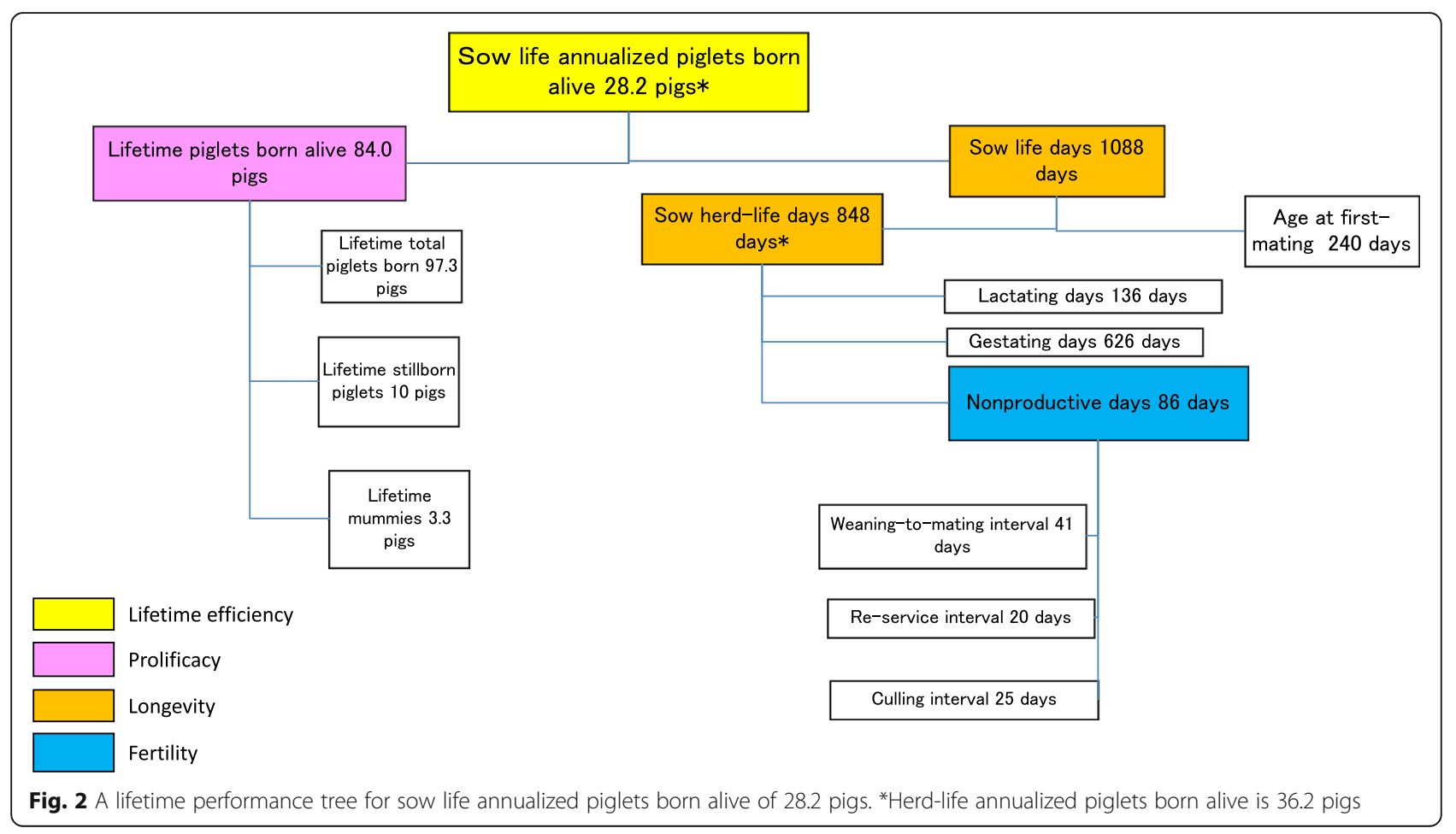


or herd-life annualized PBA is produced from lifetime PBA and either sow life days or herd-life days.

\section{Sow longevity}

Longevity of sows is commonly measured as the number of parity at removal [2-5]. In North America, Japan, Sweden and Spain, the mean parity at removal varies between 3.3 and 5.6 [11-15]. However, parity at removal is not an accurate way to monitor sow longevity because the parity at removal does not take the number of sow days into account, which can vary between herds for sows in the same parity. Therefore, sow life days or herd-life days should be used to measure longevity.

Mean herd-life days varies between 467 and 969 days in the U.S.A., the E.U. and Japan [9, 11, 16]. Longevity can be also measured as sow life days. Studies have shown mean sow life days ranging between 992 and 1088 days in the E.U. and Japan $[10,11]$.

\section{Prolificacy}

Prolificacy is represented by lifetime PBA, from the first farrowing to removal. Also, prolificacy depends on the number of parity at removal because the number of PBA increases with each farrowing up to parity $5[13,17]$. Prolificacy is affected by genetics and breeding management including timing of insemination, semen quality and the stockman's skill $[4,18]$. Also, prolificacy per litter, measured as the number of PBA per litter, is limited by ovulation rate and embryonic survival [19], but there has been significant improvement in prolificacy over the last few decades due to genetic progress in the swine industry $[3,20]$. Prolificacy can also be decreased by abortions and deaths, because these reduce sow longevity.

\section{Fertility}

Fertility is commonly measured as the number of litters farrowed per sow during a certain period such as a year [4]. However, over $50 \%$ of sows live for several years in a herd, so using the number of litters per sow over a period of 1 year is probably not the best way to accurately measure lifetime fertility because it will not take account of all the factors that could affect a sow's fertility throughout its herd-life. Sow fertility can also be measured by lifetime nonproductive days which is directly associated with the number of litters farrowed in sow herd-life [4]. Sow lifetime nonproductive days is derived from re-service interval, weaning-to-first-mating interval and culling interval [5, 7]. Re-service interval and weaning-to-first-mating interval account for approximately $60 \%$ of the nonproductive days [21]. In particular, weaning-to-first-mating interval is closely related to the key reproductive hormone $\mathrm{LH}$ which mainly controls the fertility of sows [22, 23]. Also, re-service interval is related to occurrences of conception or pregnancy failure. Abortions in gilts and sows will also increase nonproductive days such as the re-service interval or culling interval [24]. Another factor critical for fertility is sow mortality, because increased mortality increases death interval, i.e. the number of days from a last event to the pig's death, such as last-weaning-to-death interval of sows or last-mating-to-death interval of gilts, which increases nonproductive days.

\section{Lifetime efficiency based on piglets weaned $(P W)$ or piglets born live (PBA)}

Annualized PW is a measure of sow lifetime efficiency calculated from lifetime PW divided by sow life days or herd-life days $\times 365.25$ (Fig. 1). Also, annualized PBA is a measure of sow efficiency calculated from lifetime PBA divided by sow life days or herd-life days $\times 365.25$ (Fig. 2).

It should be noted that the herd-life annualized PW of a sow can be very high if the sow is culled immediately after weaning in parity 1 . For example, culling a parity 1 sow immediately after weaning 14 piglets at 22 days of age would produce a herd-life annualized PW of 37: 14 PW / $(115+22)$ days $\times 365.25$ days. This is a major drawback of using herd-life annualized PW. Culling a sow in parity 1 does not decrease the herd-life efficiency of the culled sow, but it does decrease sow efficiency measured as sow life annualized PW. For example, if the parity 1 sow mentioned earlier in this paragraph had AFM 240 days, then culling the sow in parity 1 would produce only 13.6 sow life annualized PW: $14 \mathrm{PW} /(240+115+$ $22)$ days $\times 365.25$ days. It would also only produce sow life annualized PBA of 13.6 pigs, if this parity 1 sow, that had farrowed PBA 14 pigs, was culled immediately after weaning.

\section{Sow level predictors for lifetime performance}

There are some measures of reproductive performance which are also predictors for sow lifetime performance [5]. Sow lifetime reproductive performance can be predicted to a certain degree using these performance factors.

\section{Age of gilts at first-mating (AFM)}

In North America, Spain, Portugal, Italy and Japan, the typical AFM is approximately 240 days, ranging between 160 and 370 days $[4,5,25]$. It is currently recommended to start mating gilts from 203 days of age in order to let replacement gilts gain enough body weight and body fat for first-mating [26].

Ages of gilts at first estrus can be recorded in major software with dates of heat-no-service events. The age of gilts at first estrus indicate age of puberty with the first ovulation, and early matured gilts with early age at first estrus have been associated with high lifetime performance $[3,27]$. So, age of gilts at first estrus and dates of heat-no-service events are useful for predicting sow 
lifetime performance. However, neither measurement is commonly recorded in commercial herds [3, 27], whereas AFM is well recorded. Therefore, AFM is an important factor in farm data analysis for predicting lifetime performance of sows in breeding herds.

Late AFM has been associated with decreased longevity (i.e. removed at lower parity or shorter herd-life days), decreased prolificacy (i.e. fewer lifetime PBA), decreased fertility (i.e. more nonproductive days during herd-life) and decreased efficiency (i.e. fewer annualized PW or PBA) [11, 25]. For example, a study showed that sows first mated at 278 days of age or later were removed at lower parity and had fewer lifetime PBA than those mated at 229 days or earlier of age [27]. Late AFM has also been associated with more occurrences of late returns to service [28], which could be because late maturing gilts have poorly developed ovary and corpora lutea functions, and low progesterone concentrations [29]. Also, studies have shown that late AFM sows had a longer weaning-to-first-mating interval than early AFM sows, and so consequently prolonged nonproductive days or low fertility [25, 30]. Conversely, other studies showed that late AFM sows produced a small increase of 0.3-0.4 PBA when AFM increased by 100 days [31, 32].

Late AFM sows are also likely to become lowefficiency sows as a result of re-service interval or culling interval. Additionally, low lifetime performance of late AFM gilts is related to being overweight at breeding [31] which negatively affects sow longevity and lifetime efficiency such as annualized PW or PBA.

\section{Body weights of gilts}

The reproductive system of gilts is not fully matured, so appropriate nutrition management is needed during gilt development to provide them with the nutrients and energy necessary to achieve the target growth rate and body reserves $[26,33,34]$. A body mass of $>180 \mathrm{~kg}$ after farrowing is recommended to protect against the detrimental effects of fat and lean tissue loss during the first lactation on subsequent reproductive performance [35, 36]. Thus, if gilts are mated when they are at 135 to 150 $\mathrm{kg}$, they would be at the target weight at farrowing assuming a weight gain of 35 to $40 \mathrm{~kg}$ during gestation [3].

\section{Re-service in parities 0 and 1}

Return-to-service is a common occurrence in breeding herds. Approximately $10 \%$ of first-serviced sows do not conceive or conceive but fail to maintain pregnancy, and are then re-serviced. Furthermore, their farrowing rates decrease by $10 \%$ with each re-service [37]. The same study also found that re-serviced gilts had greater herdlife nonproductive days ( 124 vs. 175 days), lower parity at culling (4.2 vs. 3.8) and fewer herd-life PBA (46.2 vs. 44.2 pigs) than non-return gilts [37]. Furthermore, other studies have also found negative effects of return-toservice in gilts. For example, $41 \%$ of first-returned gilts had a second return in later life, compared with only $9 \%$ of returned sows in parity 6 having a second return [28]. Also, 36\% of re-serviced parity 1 sows had one or more returns in later life [28], and re-serviced parity 1 sows had lower farrowing rates in subsequent parties than non-return sows [37-39].

Returned sows tend to have short estrus duration or weak estrus signs [40], which make it hard to detect estrus signs for appropriate timing of inseminations $[18,37,41]$. Also, any return occurrence increases a sow's nonproductive days and decreases its fertility and efficiency. Therefore, returned sows should be closely monitored, because re-servicing the returned sows is an opportunity to improve sow efficiency $[39,41]$. A general rule is to cull gilts or sows having two repeats, and in addition we recommend providing careful day-today management to monitor mated gilts and sows at risk of having a return $[4,41]$.

\section{Number of piglets born alive (PBA) in parity 1}

The number of PBA in parity 1 is an early predictor of sow prolificacy. In a study, sows were categorized into 4 groups based on the 10th, 50th and 90th percentiles of PBA in parity 1 , and the sow group that had the most PBA in parity 1 produced more annualized PBA than the group that had fewest PBA in parity $1[25,42]$. A sow's prolificacy can be predicted by its PBA in parity 1 , suggesting that prolificacy could be increased by gilt development and breeding programs and genetic potential $[3,43]$. So, a gilt development unit is important to raise more highly prolific sows. However, E.U. and Japanese studies have not found any difference in weaning-to-firstmating interval or 21-day adjusted litter weights between the prolificacy groups based on PBA in parity $1[25,42]$.

\section{Birth weight, weaning weight and pre-weaning growth rate} Highly prolific sows in genetic parent stocks can be a concern with regard to future replacement gilts. This is because more PBA in a litter is associated with a lower birth weight, and replacement gilts with a low birth weight will have compromised growth, reproductive performance and sow longevity [3, 44, 45]. Birth weight and pre-weaning growth rate in piglets to be replacement gilts are characteristics of litter-of-origin for lifetime performance of sows [44]. Lower pre-weaning growth rate is related to lower post-weaning growth performance [45], late puberty [44] and consequently late AFM.

Gilts with a low birth weight are associated with intrauterine growth retardation [46], and have fewer medium size follicles and more atretic follicles on the ovary than gilts with a high birth weight, when approaching expected puberty age [47]. Therefore, gilts with a low birth 
weight should not be selected, nor should those born to sows that have farrowed a large litter with large variation in birth weights. In addition to reproductive performance, high weaning weight and high pre-weaning growth of gilt piglets are associated with high survival and good performance as replacement gilts [48].

\section{Use of nurse sows}

While the use of foster-in and nurse-sow techniques can increase the number of $\mathrm{PW}$ and produce heavier litter weights at weaning, it could decrease the foster or nurse sow's post weaning reproductive performance due to increased loss of body reserves and impaired metabolic state in the lactating sow [22, 49]. However, it has been found that nurse sows had farrowing rates and PBA similar to non-nurse sows in any parity, and the only difference was that they had a prolonged weaning-tofirst-mating interval [50]. Consequently, the nurse sows produced 3-7 more herd-life annualized PW than nonnurse sows. However, it should be noted that the nurse sows appear to have been chosen as suitable sows to nurse another litter based on having good body reserves, nursing behavior and high feed intake during lactation.

\section{Number of stillborn piglets in parity 1}

Stillborn piglets are theoretically defined as piglets that are alive at the initiation of farrowing but die intrapartum [4], whereas, in practice, any piglet found dead behind a sow at the first check up after parturition, with no sign of mummification, is categorized as a stillborn piglet [51].

The number of stillborn piglets in parity 1 can be related to other aspects of sow lifetime performance. An increased number of stillborn piglets has been associated with decreased 21-day adjusted litter weights [52], more occurrences of uterine prolapse [53] or abortions at subsequent pregnancy [24], decreased farrowing rate, decreased PBA at subsequent parity, low prolificacy, low milk yields and probably low longevity due to low fertility [52]. Such negative associations of stillborn piglets are related to difficult farrowing, large litter size and shorter gestation length as sow factors and herd health conditions as environment factors [51, 54]. Therefore, supervision and assisted farrowing can help sows with difficult farrowing to overcome uterine inertia [51, 55]. In addition, caring for piglets by drying and warming them, and clearing their airways can help to reduce the number of stillborn piglets $[54,55]$. Also, it is advisable to have herd health programs, especially for parity 1 sows, to reduce the risk of having stillborn piglets due to such infectious diseases. Antibiotic treatments are recommended for sows that have farrowed many stillborn piglets or that had dystocia [54, 56]. Moreover, it is important to note that the repeatability of sows' farrowing stillborn piglets is low, and so there is no justification for culling low-parity sows based on the number of stillborn piglets in parity 1 [52].

\section{Weaning-to-first-mating interval in parity 1}

Parity 1 sows with weaning-to-first-mating interval 720 days have lower farrowing rates and fewer PBA in subsequent parities than those with weaning-to-firstmating interval 3-6 days [38, 57]. Another study showed that parity 1 sows with weaning-to-first-mating interval 4 days had 0.3 more herd-life annualized PBA than those with weaning-to-first-mating interval 5 days (Fig. 3). So, it suggested that parity 1 sows with a weaning-to-firstmating interval 4 days were the most efficient [58]. Also, the same study showed that there was little difference in herd-life annualized PBA between parity 1 sows with a weaning-to-first-mating interval $0-3$ days and those with weaning-to-first-mating interval 4 and 5 days. So, it suggests that parity 1 sows with weaning-to-first-mating interval 0-3 days were capable of having the same lifetime efficiency as those with weaning-to-first-mating interval 4 or 5 days.

Prolonged weaning-to-first-mating interval is related to a short duration of estrus and a shorter interval between onset of estrus and ovulation, regardless of parity [59, 60], which increases the risk of suboptimal timing of insemination and can cause the sows to have low farrowing rates and few PBA. Also, especially for parity 1 sows, weaningto-first-mating interval tends to be increased by low feed intake during lactation and short lactation length $[61,62]$. Additionally, there has been progress in genetic programs selecting for decreased weaning-to-first-mating interval which has helped to reduce the probability of a return [63].

\section{Abortion in parities 0 and 1}

Abortion is maternal failure in some sows [64] due to endocrine disturbances or uterine problems or infection agents such as porcine parvovirus and porcine reproductive and respiratory syndrome virus [56]. It has been reported that 43-44\% aborted sows in parities 0 and 1 were culled without any re-service [24], presumably because it was thought that aborted sows were more likely than non-aborted sows to abort in a later pregnancy, and so they have lower longevity than non-aborted sows. However, no large differences were found between the aborted sows and nonaborted sows for subsequent farrowing rate, weaning-tofirst-mating interval or lifetime performance [24]. Also, only $4.1 \%$ of sows re-serviced after a first abortion experienced a second abortion in the same or a later parity. So, it is recommended that producers re-service aborted sows at the second return to estrus, just like non-aborted sows.

\section{Peri-farrowing and lactation care in parity 1}

High summer temperature during farrowing increased sow mortality in low parity [65]. A cooling pad has been 


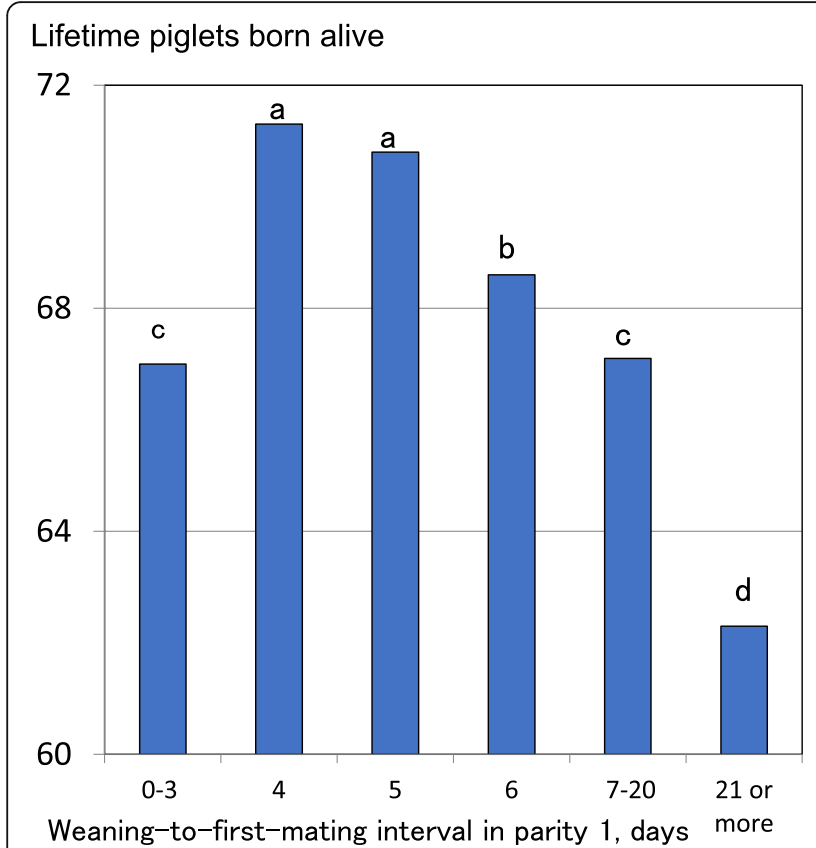

Herd-life annualized piglets born alive

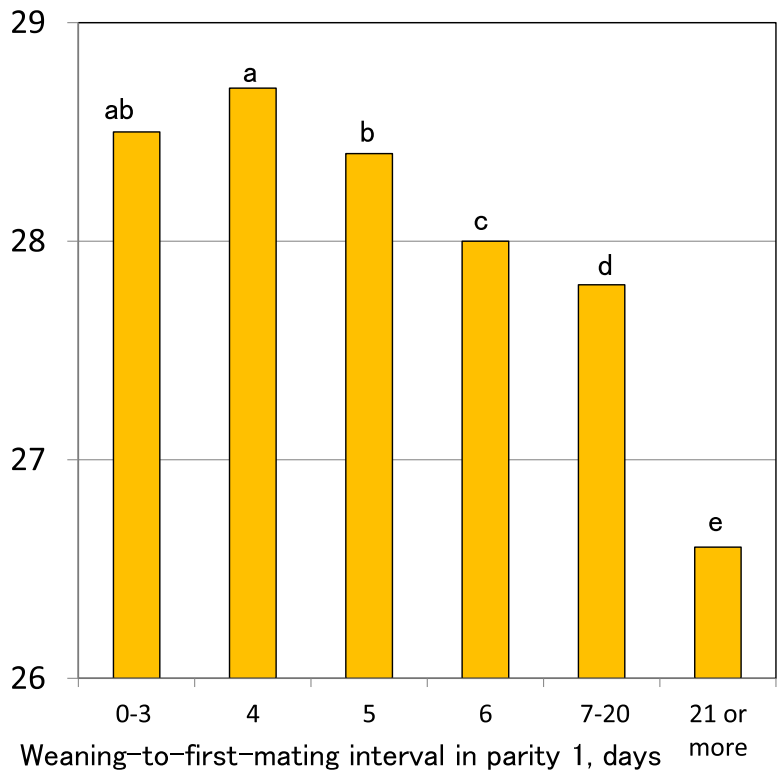

Fig. 3 Comparisons of lifetime performance of sows between six weaning-to-first-mating interval groups in parity 1 [58]. ${ }^{a-e}$ Different superscripts represent significant differences in means

developed that efficiently removes excess of heat from lactating sows [66]. So, advanced equipment in farrowing barns and increased care during the peri-partum and lactation period could help decrease sow mortality and increase longevity.

Also, decreased feed intake during lactation in parity 1 sows has been clearly associated with lower adjusted 21day litter weights, prolonged weaning-to-first-mating interval, lower farrowing rate and fewer PBA at subsequent parity and an increased risk of culling due to anestrus or reproductive failure [19,67-69]. So, it seems clear that increasing feed intake during lactation in parity 1 sows increases longevity, fertility, prolificacy and efficiency of sows.

\section{Lameness occurrences}

Sows culled due to lameness have lower longevity, lower fertility, lower prolificacy and lower efficiency than those culled for other reasons [5, 12, 70]. Lameness increased the risk of culling from a herd [71], and it was also found that sows with leg lesions were likely to farrow more mummified fetuses and stillborn piglets than those without lesions [70].

Approximately $70 \%$ of the sows culled due to lameness were farrowed sows, whereas only $30 \%$ were serviced sows. Culling due to lameness frequently occurred 4-8 weeks after farrowing and 4-5 weeks after service, whereas risk factors were high parity and being reserviced [72]. Therefore, producers are recommended to identify sows with early signs of lameness and move them to a sick pen for recovery [73]. Also, management options that have been shown to protect against lameness include non-slated floors, dry and clean floors and the use of bedding for group housed gilts [71, 73, 74]. Furthermore, management during gilt development should provide appropriate nutrients and energy needed for required growth, as well as bones and reproductive tract development [75].

\section{Birth cohort effects}

Birth year or herd-entry year effects sow performance and longevity. Genetic progress has enabled sow reproductive performance to improve in recent birth years or herd-entry years. For example, over the last few decades, PBA per sow has been increasing in breeding herds $[6,20,76]$.

Birth year or herd entry year has also affected culling due to lameness in herd-entry cohorts, with the incidence rate for culling increasing by 25\% from 2011 to 2013 [72]. One possible reason for the increased culling of lame sows that were entered into herds from 2013 is that pregnant sows in group housing tend to exhibit more lameness than those in individual stalls [77-79], and group housing for gestating sows in mid-late pregnancy has been mandatory in the E.U. since January 2013 [80].

\section{Herd-level factors for lifetime performance}

Herd-level factors, including herd size, herd performance and management practices, are associated with lifetime 
performance of sows. Data relating to management practices can be collected by survey questionnaires, because producers do not commonly record such herd-level information in their recording software. Also, group level or herd-level factors have been shown to interact with sow level predictors for sow lifetime performance $[11,81,82]$.

\section{Herd size}

A study of Spanish herds showed that the number of PBA in parity 1 increased by 0.3 pigs, as herd size increased from 180 to 1300 sows [11]. The reason for this increase could be that large herds have more rapid genetic improvement, better health status or better production systems with advanced facilities than small herds [83, 84]. So, herd size may be an indicator of how advanced a production system is, in terms of the amount of investment, the quality of the facilities, human resources and the level of genetic improvement, although the study of the Spanish herds did also show that large herds had lower longevity of sows than small-to-mid herds [11].

Late AFM interacting with herd size has been shown to decrease sow longevity, prolificacy, fertility and efficiency of sows more in large herds than in small-to-mid herds [11]. Figure 4 shows that increased AFM decreased sow longevity 3-4 times more in sows in large herds than those in small-to-mid herds. It appears that the herd size alters the impact of AFM on sow longevity and lifetime performance.

\section{High-performing herds}

The concept of high-performing herds based on PSY has been used to provide target values for reproductive performance and productivity in breeding herds [83, 84]. The high productivity of high-performing herds is attributable to better replacement gilt development [27, 84, 85], better breeding management $[84,85]$, more advanced technologies such as cooling systems, post cervical AI or assisted colostrum intake [86, 87] and better piglet care during lactation $[87,88]$. For example, as outside temperature increased from 25 to $35 \mathrm{C}^{\mathrm{o}}$, the weaning-to-first-mating interval of sows in highperforming herds increased by only 0.3 days, compared with an increase of 0.8 days in ordinary herds [81]. So, approximately $60 \%$ ( 0.5 days $/ 0.8$ days) of the negative effects of high temperature on weaning-to-first-mating interval was able to be alleviated by the management in the high-performing herds.

High-performing herd effects interacting with PBA in parity 1 alter both the reproductive potential of sows across parities and their lifetime performance. Figure 5 shows comparisons of PBA by high-prolific and lowprolific sows in either high- or low-performing herds [82]. In parities 2-6, the high- and low-prolific sows in the high-performing herds had respectively $0.8-1.1$ and
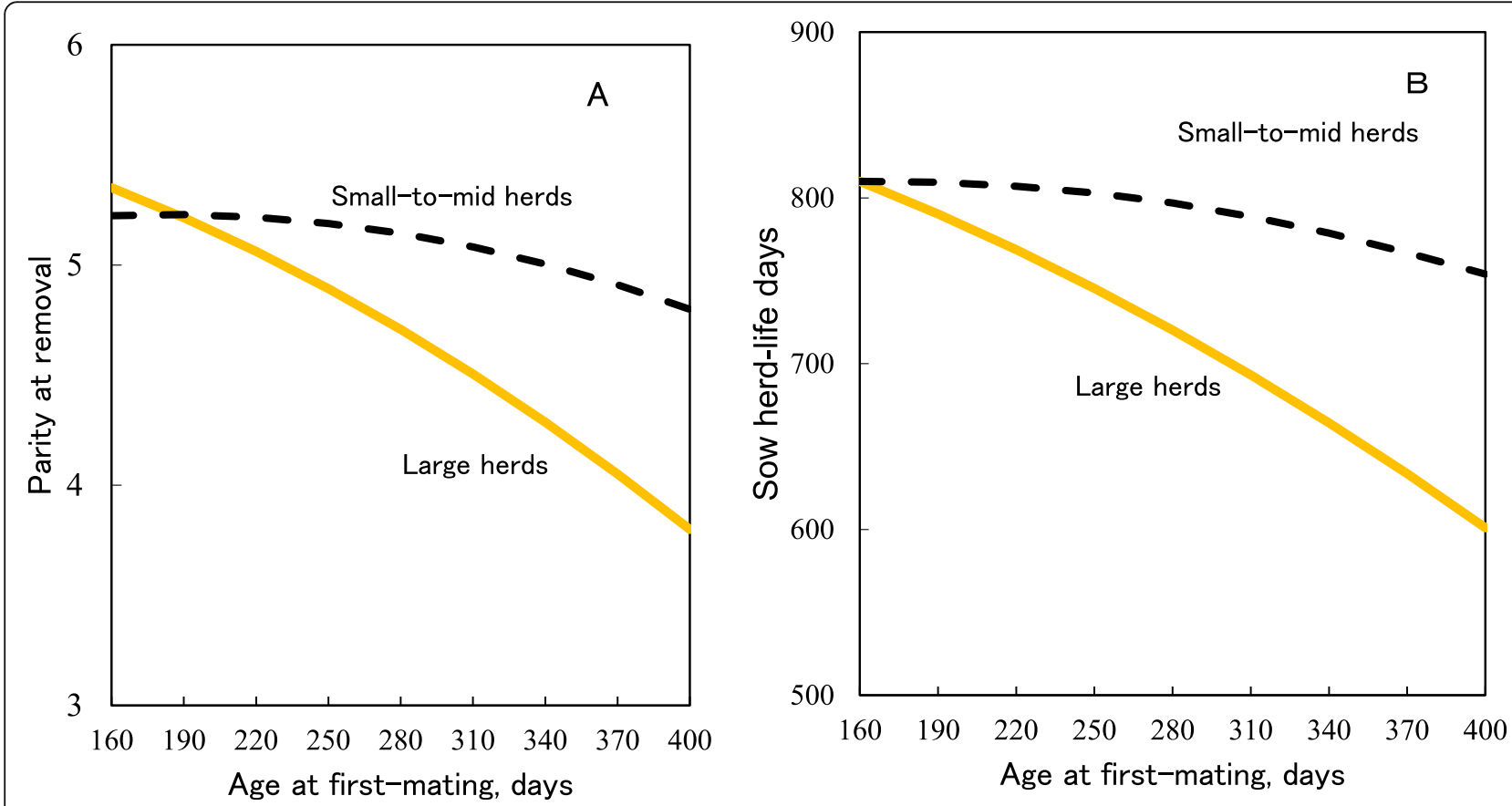

Fig. 4 Predicted parity at removal (a) and sow herd-life days (b) at different gilt ages at first-mating [11]. Herds were categorized into two groups based on the 75 th percentile of farm means of herd size: large $(\geq 1,017$ sows) or small-to-mid herds $(<1,017$ sows) 

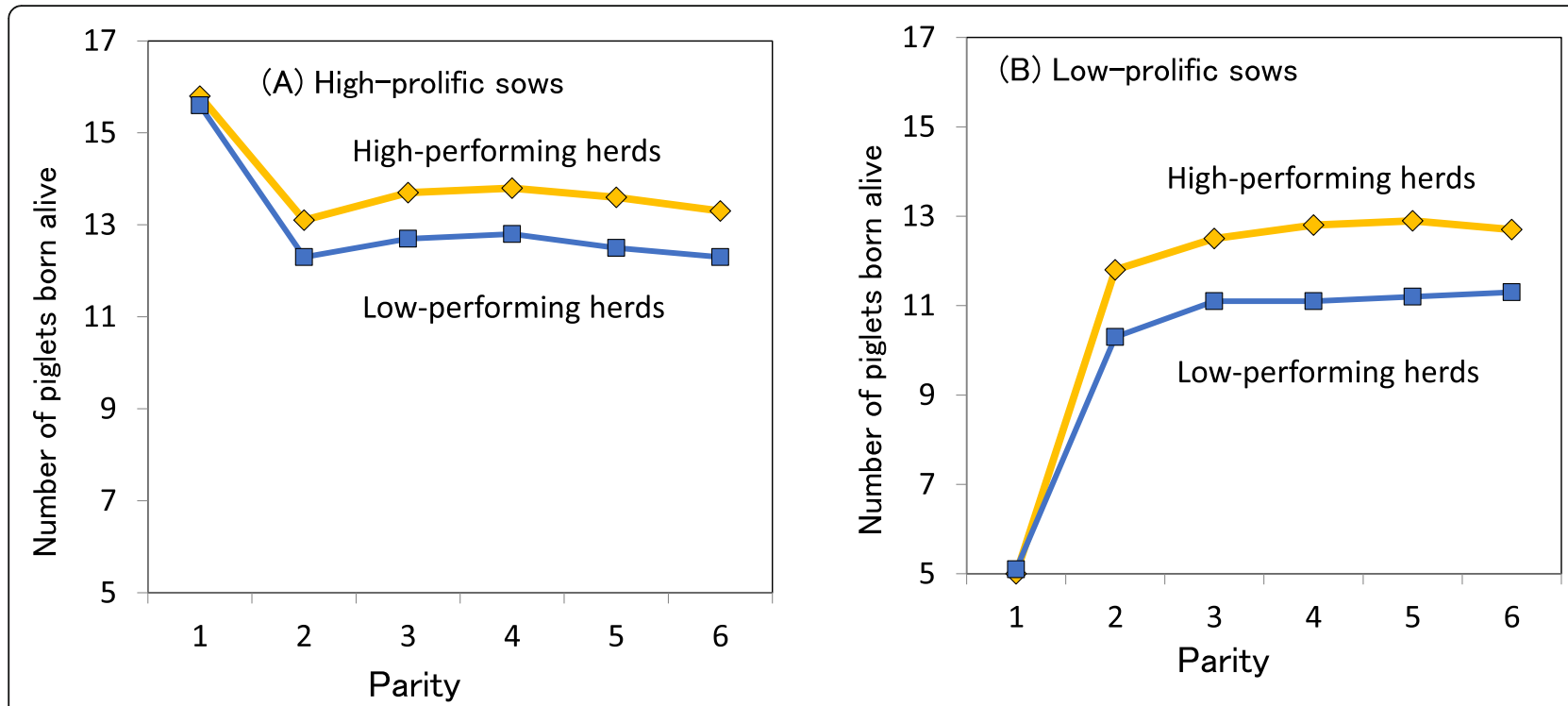

Fig. 5 Comparisons between the herd group of the number of piglets born alive of either high-prolific (a) or low-prolific sows (b) across parities [82]. The two farm groups were categorized by the 25th and 75th percentiles of herd means of herd-life annualized PW, whereas two sow groups were grouped by the 25th and 75th percentiles of the numbers of piglets born alive parity 1

1.4-1.7 more PBA than the equivalent sow groups in the low-performing herds.

\section{Timing of insemination in parity 0}

Analysis of survey data has shown that gilts in herds that perform first insemination immediately after first detection of estrus have a higher farrowing rate than those in herds that perform later insemination [18, 89]. A possible reason for the difference in farrowing rates is that gilts with delayed insemination timing might have had a shorter estrus duration, and so would be more likely to have suboptimal timing of insemination [40]. Consequently, the lower farrowing performance of such gilts with delayed insemination would result in suboptimal lifetime performance, such as low longevity, due to early culling for low fertility. Therefore, if a low farrowing rate problem is diagnosed as being related to insemination timing, it is advisable for farm staff to try for an earlier timing of insemination.

\section{Culling guidelines}

Increased culling interval increases sow nonproductive days $[4,5]$, decreases fertility and decreases efficiency. In a herd survey, the mean culling guidelines for unmated gilts and for mated gilts due to conception failure were 300 days of age and 37 days from the last mating date, respectively [90]. Furthermore, actual culling intervals for mated gilts were at least 30 days longer than the guideline for culling interval. So, optimizing culling intervals using appropriate herd culling guidelines could improve fertility and efficiency of the sows within the herd.
Farm data analysis as an observational study

Farm data analysis is an epidemiological observational study. As an observational study, there are no true replicates which controlled experiments should have. However, an observational study with appropriate statistical models can provide practical and readily applicable information to swine veterinarians and producers about real world events and practices that are difficult to investigate using controlled experiments. Also, an observational study is a powerful tool to quantify associations between outcomes and possible risk factors using big data from digital technologies [1].

There are sow level and herd-level farm data analyses. At sow level, sow performances differ in genetics, weaning weight, raising environment, parity, season, farm staff and management practices. So, observational studies of actual farm situations are useful to cope with the variation in sows on farms with different conditions. Also, sow data within a herd could fit to a two-level mixed model, because sows are not independent of the herd having different situations. Additionally, a longitudinal study of sows in farm data analysis should treat parity records in a 3-level structure: parity records within the sow in the herd.

Herd-level analysis is simple and can be useful for exploring a time trend or for providing an overview of herd performance over a long period, because there could be large changes in the management, health conditions and genetics of the herd over the study period, for example over a 10-year period. However, with herdlevel analyses, it is not possible to perform multivariate analyses to account for the variation due to sow level 
factors such as parity, season, lactation length, herdentry year, and their interactions; whereas these analyses can be performed with sow level analysis.

\section{Discussion}

We have defined and organized the four components in sow lifetime performance in two tree forms. In the sow lifetime performance trees, annualized PW and annualized PBA measured as lifetime efficiency are proposed as integrated measurements for sow lifetime performance.

Probably, annualized PBA is better than annualized PW for measuring a sow's lifetime performance without taking management or facility impacts into account, especially when considering the use of nurse sows, fostering practices or advanced facilities (e.g. milk replacer feeders) in commercial herds. However, annualized PBA does not cover lactational performance details, including milking capability. Also, while adjusted 21-day litter weight is a measure of milking capability in farm data analysis $[4,5]$, it is not commonly recorded.

For longevity, sow life days can be an appropriate measurement for producers who raise replacement gilts from birth to removal on the same farm or within the same production system. In such systems, the number of days taken to raise the gilts should be counted toward longevity. In contrast, herd-life days is a useful measurement for producers who purchase replacement gilts from outside breeding companies where the cost is the price per gilt, rather than the price per day of gilt age. However, it should be noted that sow longevity may not be critical for large producers who purchase a replacement gilt batch based on PSY which the batch will produce.

Among many predictors for high lifetime performance in this review, age at first-mating is commonly measured and might be the most useful for predicting sow lifetime performance. Also, there is a link between early sexual maturity in gilts and aspects of high lifetime performance of sows such as high prolificacy, fertility and longevity [3, 27, 33]. Consequently, producers are recommended to implement effective gilt development programs with a boar exposure area in order to stimulate pubertal estrus and increase the number of early maturing gilts $[27,33]$.

PBA in parity 1 is a simple and powerful predictor for high prolificacy including more PBA in later parities. However, PBA in parity 1 should be carefully used as a predictor of sow lifetime performance, because some sows with large litter size have litters with extremely light birth weights which are associated with low survival and slow growth performance post weaning. A breeding herd is a provider of piglets weaned for nursery, grower and finisher phases [4]. Thus, breeding herds should produce sows that will sufficient numbers of PBA and that will produce piglets of high quality or high potential growth performance.

It should be noted that no difference was found in weaning-to-first-mating interval or adjusted 21-day litter weight between prolificacy groups based on PBA in parity $1[27,42]$, which suggests that less prolific sows are not inferior in terms of fertility or milk production. Prolificacy appears to be independent of either fertility or milking capability. So, low prolificacy does not mean either low fertile or low lifetime performance. Such low prolific but high fertility sows can take foster piglets from sows that have farrowed surplus piglets. Also, sows with high prolificacy or high fertility are more likely to have high longevity and high efficiency $[27,42,58]$.

Finally, sow data, sensor data and behavior data that have recently started being collected by digital technologies will provide a large opportunity for producers and veterinarians to monitor and care for individual sows in breeding herds $[1,80]$. Such big data collected on farms should be transformed into valuable information by farm data analysis to improve the making decision process for maximizing sows' potential, optimizing their lifetime performance and enhancing animal welfare in breeding herds. Farm data analysis can also be utilized to examine risk factors for pre-weaning mortality and the number of stillborn piglets. These are two of the most urgent areas that need further research because our tree for annualized PW indicates that the average sow loses 25 piglets or more during its lifetime as stillborn or pre-weaning dead piglets.

\section{Abbreviations}

AFM: Age of gilts at first-mating; PBA: Piglets born alive; PSY: The number of piglets weaned per sow per year; PW: Piglets weaned

Acknowledgements

Authors thank Dr. I. McTaggart for his critical review of this manuscript.

\section{Authors' contributions}

YK reviewed the topics and wrote the present article, and RI confirmed with the contents of the review. Both authors read and approved the final manuscript.

\section{Funding}

This research is supported by the Research Grant Kiban-B (2019-2021) and the Graduate School GP 2019 from Meiji University.

Availability of data and materials

Not applicable.

Ethics approval and consent to participate

Not applicable.

Consent for publication

Not applicable.

Competing interests

The authors declare that they have no competing interests. 
Received: 19 May 2020 Accepted: 5 August 2020

\section{Published online: 18 September 2020}

\section{References}

1. Piñeiro C, Morales J, Rodríguez M, Aparicio M, Manzanilla EG, Koketsu Y. Big (pig) data and the internet of the swine things. A new paradigm in the industry. Anim Front. 2019;9:6-15.

2. Stalder $K$, D'Allaire $S$, Drolet $R$, Abell $C$. Longevity in breeding animals. In: Zimmerman JJ, Karriker LA, Ramirez A, Schwartz KJ, Stevenson GW, editors. Diseases of swine. 10th ed. Chichester: Wiley; 2012. p. 50-9.

3. Paterson J, Foxcroft G. Gilt Management for Fertility and Longevity. Animals. 2019:9:434-48.

4. Dial GD, Marsh WE, Polson DD, Vaillancourt JP. 1992. Reproductive failure: differential diagnosis. In: Leman AL, Straw BE, Mengeling WL, D'Allaire S, Taylor DJ, editors, Disease of swine (7th ed.), lowa State University press, Ames; 83-137.

5. Koketsu Y, Tani S, lida R. Factors for improving reproductive performance of sows and herd productivity in commercial breeding herds. Porcine Health Manag. 2017:3:1.

6. PigCHAMP benchmarking summaries. https://www.pigchamp.com/ benchmarking/benchmarking-summaries. Accessed 16 Jul 2020

7. Koketsu Y. Longevity and efficiency associated with age structures of female pigs and herd management in commercial breeding herds. J Anim Sci. 2007:85:1086-91.

8. Tani S, Piñeiro C, Koketsu Y. Culling in served females and farrowed sows at consecutive parities in Spanish pig herds. Porcine Health Manag. 2018:4:3.

9. Rodriguez-Zas SL, Southey BR, Knox RV, Connor JF, Lowe JF, Roskamp BJ. Bioeconomic evaluation of sow longevity and profitability. J Anim Sci. 2003; 81:2915-22.

10. Sasaki $Y$, Koketsu Y. Sows having high lifetime efficiency and high longevity associated with herd productivity in commercial herds. Livestock Sci. 2008; 118:140-6.

11. Koketsu $Y$, lida R, Piñeiro C. An increased age at first-mating interacted by herd size or herd productivity decreases sow longevity and herd-life reproductive efficiency in breeding herds. Porcine Health Manag. 2020;6:2.

12. Lucia TJ, Dial GD, Marsh WE. Estimation of lifetime productivity of female swine. J Am Vet Med Assoc. 1999:214:1056-9.

13. Koketsu Y, Takahashi H, Akachi K. Longevity, lifetime pig production, and age at first mating in a cohort of gilts over 6 years. J Vet Med Sci. 1999: 61(9):1001-5.

14. Koketsu Y. Retrospective analysis of trends and production factors associated with sow mortality on swine breeding farms in the U.S.A. Prev Vet Med. 2000;46:249-56.

15. Engblom L, Lundeheim N, Dalin A-M, Andersson K. Sow removal in Swedish commercial herds. Livest Sci. 2007;106:76-86.

16. Saito H, Sasaki Y, Hoshino Y, Koketsu K. An occurrence of decreased numbers of pigs born alive in parity 2 sows in commercial herds. Livestock Sci. 2010;128:189-92

17. Bergman P, Gröhn YT, Rajala-Schultz P, Virtala A-M, Oliviero C, Peltoniemi O, Heinonen M. Sow removal in commercial herds: patterns and animal level factors in Finland. Prev Vet Med. 2018;159:30-9.

18. Kaneko M, lida R, Koketsu Y. Herd management procedures and factors associated with low farrowing rate of female pigs in Japanese commercial herds. Prev Vet Med. 2013;109:69-75.

19. Vinsky MD, Novak S, Dixon WT, Dyck MK, Foxcroft GR. Nutritional restriction in lactating primiparous sows selectively affects female embryo survival and overall litter development. Reprod Fertil Dev. 2006;18:347-55.

20. Andersson E, Frössling J, Engblom L, Algers B, Gunnarsson S. Impact of litter size on sow stayability in Swedish commercial piglet producing herds. Acta Vet Scand. 2016:58:31.

21. Koketsu Y. Six component intervals of nonproductive days in breedingfemale pigs on commercial farms in Japan. J Anim Sci. 2005;83:1406-12.

22. Koketsu Y, Dial GD, Pettigrew JE, Marsh WE, King VL. Influence of imposed feed intake patterns during lactation on reproductive performance, circulating levels of glucose, insulin and luteinizing hormone in primiparous sows. J Anim Sci. 1996;74:1036-46.

23. Soede NM, Langendijk P, Kemp B. Reproductive cycles in pigs. Anim Reprod Sci. 2011:124:251-8.

24. lida R, Piñeiro C, Koketsu Y. Abortion occurrence, repeatability and factors associated with abortions in female pigs in commercial herds. Livest Sci. 2016;185:131-5.
25. lida R, Piñeiro C, Koketsu Y. High lifetime and reproductive performance of sows in southern European Union commercial farms can be predicted by high numbers of pigs born alive at parity one. J Anim Sci. 2015;93:2501-8.

26. PIC manuals. 2017. http://www.picrsa.co.za/manuals/ Accessed 16 Mar 2020.

27. Patterson JL, Beltranena E, Foxcroft GR. The effect of gilt age at first estrus and breeding on third estrus on sow body weight changes and long-term reproductive performance. J Anim Sci. 2010;88:2500-13.

28. Tani S, Piñeiro C, Koketsu Y. Recurrence patterns and factors associated with regular, irregular and late returns-to-service of female pigs and their lifetime performance on southern European farms. J Anim Sci. 2016;94:1924-32.

29. Bertoldo MJ, Holyoake PK, Evans G, Grupen CG. Seasonal variation in the ovarian function of sows. Reprod Fert Develop. 2012;24:822-34.

30. Saito H, Sasaki Y, Koketsu Y. Associations between age of gilts at first mating and lifetime performance or culling risk in commercial herds. J Vet Med Sci. 2011;73:555-9.

31. Roongsitthichai A, Cheuchuchart $P$, Chatwijitkul S, Chantarothai $O$, Tummaruk P. Influence of age at first estrus, body weight, and average daily gain of replacement gilts on their subsequent reproductive performance as sows. Livest Sci. 2011;151:238-45.

32. Schukken YH, Buurman J, Huirne RB, Willemse AH, Vernooy JC, van den Broek J, Verheijden $\mathrm{JH}$. Evaluation of optimal age at first conception in gilts from data collected in commercial swine herds. J Anim Sci. 1994;72:1387-92.

33. Patterson J, Triemert E, Gustafson B, Werner T, Holden N, Pinilla JC, Foxcroft G. Validation of the use of exogenous gonadotropins (PG600) to increase the efficiency of gilt development programs without affecting lifetime productivity in the breeding herd. J Anim Sci. 2016;94:805-15.

34. Koketsu Y, lida R. Sow housing associated with reproductive performance in breeding herds. Mol Reprod Dev. 2017;84:979-86.

35. Małopolska MM, Tuz R, Lambert BD, Nowicki J, Schwarz T. The replacement gilt: current strategies for improvement of the breeding herd. J Swine Health Prod. 2018;26:208-14.

36. Clowes EJ, Aherne FX, Schaefer AL, Foxcroft GR, Baracos VE. Parturition body size and body protein loss during lactation influence performance during lactation and ovarian function at weaning in first parity sows. J Anim Sci. 2003;81:1517-28.

37. Koketsu Y. Re-serviced females on commercial swine breeding farms. J Vet Med Sci. 2003;65:1287-91.

38. Tummaruk P, Tantasuparuk W, Techakumphu M, Kunavongkrit A. Influence of repeat-service and weaning-to-first-service interval on farrowing proportion of gilts and sows. Prev Vet Med. 2010;96:194-200.

39. Takai $Y$, Koketsu $Y$. Number of services and the reservice intervals in relation to suboptimal reproductive performance in female pigs on commercial farms. Livest Sci. 2008;114:42-7.

40. Steverink DWB, Soede NM, Groenland GJR, van Schie FW, Noordhuizen JPTM, Kemp B. Duration of estrus in relation to reproduction results in pigs on commercial farms. J Anim Sci. 1999;77:801-9.

41. Takai $Y$, Koketsu $Y$. Identification of a female-pig profile associated with lower productivity on commercial farms. Theriogenology. 2007;68:87-92.

42. lida R, Koketsu Y. Number of pigs born alive in parity 1 sows associated with lifetime performance and removal hazard in high- or low-performing herds in Japan. Prev Vet Med. 2015;121:108-14.

43. Hoving LL, Soede NM, Graat EAM, Feitsma H, Kemp B. Reproductive performance of second parity sows: relations with subsequent reproduction. Livest Sci. 2011;140:124-30.

44. Vallet JL, Calderón-Díaz JA, Stalder KJ, Phillip C, Cushman RA, Miles JR, Rempel LA, Rohrer GA, Lents CA, Freking BA, Nonneman DJ. Litter-of-origin trait effects on gilt development. J Anim Sci. 2016;94:96-105.

45. Wolter BF, Ellis M. The effects of weaning weight and rate of growth immediately after weaning on subsequent pig growth performance and carcass characteristics. Can J Anim Sci. 2001;81:363-9.

46. Wu G, Bazer FW, Wallace JM, Spencer TE. Board-invited review: intrauterine growth retardation: implications for the animal sciences. J Anim Sci. 2006; 84:2316-37.

47. Almeida F, Dias AA, Moreira LP, Fiúza ATL, Chiarini-Garcia H. Ovarian follicle development and genital tract characteristics in different birthweight gilts at 150 days of age. Reprod Domest Anim. 2017:52:756-62.

48. Douglas SL, Edwards SA, Kyriazakis I. Management strategies to improve the performance of low birth weight pigs to weaning and their long-term consequences. J Anim Sci. 2014;92:2280-8.

49. Quesnel $\mathrm{H}$, Etienne M, Père MC. Influence of litter size on metabolic status and reproductive axis in primiparous sows. J Anim Sci. 2007;85:118-28. 
50. lida R, Yatabe $Y$, Piñeiro $C$, Koketsu Y. Nurse sows' reproductive performance in different parities and lifetime productivity in Spain. Agric Sci. 2019;11:29-38

51. Vanderhaeghe C, Dewulf J, de Kruif A, Maes D. Non-infectious factors associated with stillbirth in pigs: a review. Anim Reprod Sci. 2013;139:76-88.

52. Hoshino Y, Koketsu Y. Assessment of post-farrowing performance in sows having a high number of pigs born dead on commercial farms. Livest Sci. 2009;125:244-8.

53. lida R, Piñeiro C, Koketsu Y. Incidences and risk factors for prolapse removal in Spanish sow herds. Prev Vet Med. 2019;163:79-86.

54. Cutler RS, Fahy VA, Spicer EM, Cronin GM. Preweaning mortality. pp. 9851002. In: Straw BE, D'Allaire S, Mengeling WL, Taylor DJ, editors. Diseases of Swine. 8th ed. Ames: Iowa State University Press; 1999. p. 985-1002.

55. Holyoake PK, Dial GD, Trigg T, King VL. Reducing pig mortality through supervision during the perinatal period. J Anim Sci. 1995;73:3543-51.

56. Almond GW, Flowers WL, Batista L, D'Allaire S. Diseases of the reproductive system. In: Straw BE, Zimmerman JJ, D'Allaire S, Taylor DJ, editors. Diseases of swine. 9th ed. Ames: Blackwell publishing; 2006. p. 113-47.

57. Hoshino Y, Koketsu Y. A repeatability assessment of sows mated 4-6 days after weaning in breeding herds. Anim Reprod Sci. 2008;108:22-8.

58. Yatabe $Y$, lida R, Piñeiro C, Koketsu Y. Recurrence patterns and lifetime performance of parity 1 sows in breeding herds with different weaning-tofirst-mating intervals. Porcine Health Manag. 2019;5:15.

59. Weitze KF, Wagner-Rietschel H, Waberski D, Richte L, Krieter J. The onset of heat after weaning, heat duration, and ovulation as major factors in $\mathrm{Al}$ timing in sows. Reprod Domest Anim. 1994;29:433-43.

60. Kemp B, Soede NM. Relationship of weaning-to-estrus interval to timing of ovulation and fertilization in sows. J Anim Sci. 1996;74:944-9.

61. Koketsu Y, Dial GD. Factors associated with prolonged weaning-to-mating interval among sows on farms that wean early. J Am Vet Med Assoc. 1997; 211:894-8.

62. Koketsu Y, Dial GD. Factors influencing the post weaning reproductive performance of sows on commercial farms. Theriogenology. 1997;47:1445-61.

63. Holm B, Bakken M, Vangen R, Rekaya R. Genetic analysis of age at first service, return rate, litter size, and weaning-to-first service interval of gilts and sows. J Anim Sci. 2005:83:41-8.

64. Meredith MJ. Pig breeding and infertility. In: Meredith MJ, editor. Animal breeding and infertility. Oxford: Blackwell Science; 1995. p. 278-353.

65. lida R, Koketsu Y. Climatic factors associated with peripartum pig deaths during hot and humid or cold seasons. Prev Vet Med. 2014;115:166-72.

66. Cabezon FA, Schinckel AP, Richert BT, Peralta WA, Gandarillas M. Development and application of a model of heat production for lactating sows. J Anim Sci. 2017;95(Suppl 2):30.

67. Koketsu Y, Dial GD, Pettigrew JE, King VL. Feed intake pattern during lactation and subsequent reproductive performance of sows. J Anim Sci. 1996;74:2875-84.

68. Gourley KM, Calderon HI, Woodworth JC, DeRouchey JM, Tokach MD, Dritz SS, Goodband RD. Sow and piglet traits associated with piglet survival at birth and to weaning. J Anim Sci. 2020;98:1525-3163.

69. Koketsu Y, Dial GD, King VL. Returns to service after mating and removal of sows for reproductive reasons from commercial swine farms. Theriogenology. 1997;47:1347-63.

70. Anil SS, Anil L, Deen J. Effects of lameness on sow longevity. Am Vet Med Assoc. 2009;235:734-8.

71. Pluym L, Van Nuffel A, Van Weyenberg S, Maes D. Prevalence of lameness and claw lesions during different stages in the reproductive cycle of sows and the impact on reproduction results. Animal. 2013;7:1174-81.

72. lida R, Piñeiro C, Koketsu Y. Removal of sows in Spanish breeding herds due to lameness: incidence, related factors and reproductive performance of removed sows. Prev Vet Med. 2020;179:105002.

73. Maes D, Pluym L, Peltoniemi O. Impact of group housing of pregnant sows on health. Porcine Health Manag. 2016;2:17.

74. Gjein H, Larssen R. The effect of claw lesions and claw infections on lameness in loose housing of pregnant sows. Acta Vet Scand. 1995;36: 451-9.

75. Swine Nutrition Guide 2019 Edition. KSU, Applied Swine Nutrition. https:// www.asi.k-state.edu/research-and-extension/swine/swinenutritionguide/ sow_nutrition/SN1_GiltDevelopment_Final.pdf Accessed 10 Jul 2020.

76. Nielsen S, Kristensen AR, Moustsen VA. Litter size of Danish crossbred sows increased without changes in sow body dimensions over a thirteen year period. Livest Sci. 2018;209:73-6.
77. Harris MJ, Pajor EA, Sorrells AD, Eicher SD, Richert BT, Marchant-Forde JN. Effects of stall or small group gestation housing on the production, health and behaviour of gilts. Livest Sci. 2006;102:171-4.

78. Anil SS, Anil L, Deen J, Baidoo S, Walker RD. Factors associated with claw lesions in gestating sows. Swine Health Prod. 2007;15:78-83.

79. lida R, Piñeiro C, Koketsu Y. Behaviors, displacement and pregnancy loss in pigs under an electronic sow feeder system. J Agric Sci. 2017;912:43-53.

80. European commission. Animal welfare in practices, 2015. http://ec. europa.eu/food/animals/welfare/practice/farm/index_en.htm. Accessed 28 Dec 2016

81. lida R, Koketsu Y. Interactions between pre- or postservice climatic factors, parity, and weaning-to-first-mating interval for total number of pigs born of female pigs serviced during hot and humid or cold seasons. J Anim Sci. 2014;92:4180-8

82. Tani S, Piñeiro C, Koketsu Y. High-performing farms exploit reproductive potential of high or low prolific sows better than low-performing farms. Porcine Health Manag. 2018;4:15.

83. King VL, Koketsu Y, Reeves D, Xue JL, Dial GD. Management factors associated with swine breeding-herd productivity in the United States. Prev Vet Med. 1998;35:255-64.

84. Koketsu Y. Productivity characteristics of high-performing swine farms. J Am Vet Med Assoc. 2000;215:376-9.

85. Amaral Filha WS, Bernardi ML, Wentz I, Bortolozzo FP. Growth rate and age at boar exposure as factors influencing gilt puberty. Livest Sci. 2009:120:51-7.

86. Kraeling RR, Webel SK. Current strategies for reproductive management of gilts and sows in North America. J Anim Sci Biotechnol. 2015;6:3.

87. Knox RV. Impact of swine reproductive technologies on pig and global food production. Adv Exp Med Biol. 2014;752:131-60.

88. Muns R, Nuntapaitoon M, Tummaruk P. Non-infectious causes of preweaning mortality in piglets. Livest Sci. 2016;184:46-57.

89. Kaneko M, Koketsu Y. Gilt development and mating in commercial swine herds with varying reproductive performance. Theriogenology. 2012;77:840-6.

90. Sasaki $Y$, Koketsu $Y$. A herd management survey on culling guidelines and actual culling practices in three herd groups based on reproductive productivity in Japanese commercial swine herds. J Anim Sci. 2012;90:1995-2002.

\section{Publisher's Note}

Springer Nature remains neutral with regard to jurisdictional claims in published maps and institutional affiliations.
Ready to submit your research? Choose BMC and benefit from:

- fast, convenient online submission

- thorough peer review by experienced researchers in your field

- rapid publication on acceptance

- support for research data, including large and complex data types

- gold Open Access which fosters wider collaboration and increased citations

- maximum visibility for your research: over $100 \mathrm{M}$ website views per year

At $\mathrm{BMC}$, research is always in progress.

Learn more biomedcentral.com/submissions 